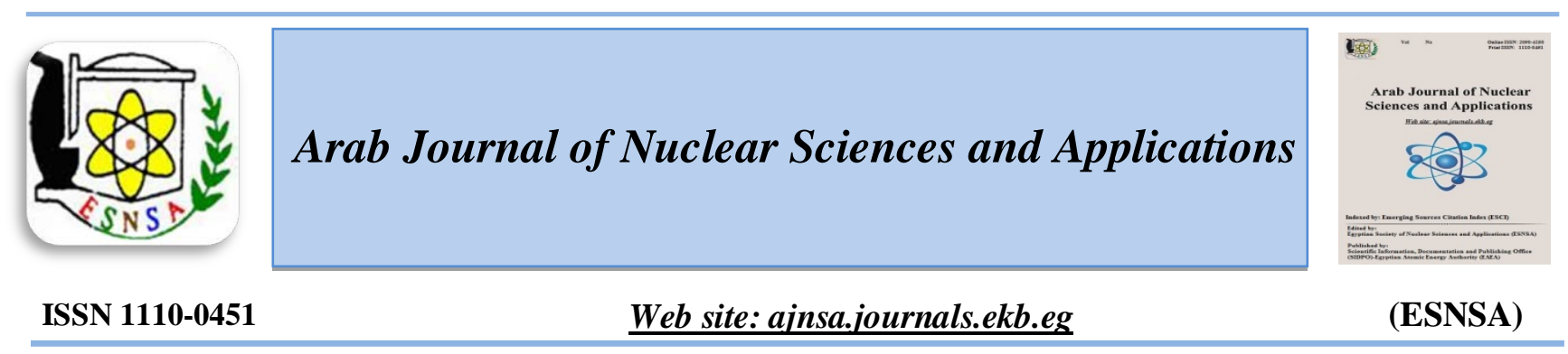

\title{
Low Cost Natural Adsorbent for Removal of Pb (II) Ions from Waste Solutions
}

\author{
E.A. Abdel-Galil, H.E. Rizk ${ }^{*}$ and W.M. El-kenany \\ Hot Laboratories Center, Atomic Energy Authority, Cairo, Egypt
}

\begin{abstract}
Received 20 $0^{\text {th }} \mathrm{Dec} .2017$ In this paper, the adsorption behavior of $\mathrm{Pb}^{2+}$ ions from aqueous solutions onto castor stem as a natural Accepted $23^{\text {th }}$ Jan. 2018 adsorbent was investigated under various experimental conditions. Characterization of castor sorbent was evaluated by SEM, XRD, FTIR, TGA, BET surface area analysis, and CHNS elemental analyses. Operational parameters such as $\mathrm{pH}$, contact time, initial ion concentrations, sorbent amount, particle size, competing ions, and temperature were also studied. Adsorption data fitted well with the Langmuir and Freundlich models. However, Freundlich isotherm displayed a better fitting model than Langmuir isotherm because of the higher correlation coefficient that the former exhibited, thus, indicating the applicability of multilayer coverage of the $\mathrm{Pb}$ (II) on the surface of adsorbent. On the basis of distribution studies, the distribution coefficient $\left(K_{d}\right)$ increases with increasing the reaction temperature of the solution. Thermodynamic parameters, $\Delta \mathbf{H}^{0}, \Delta \mathbf{G}^{0}$, and $\Delta \mathbf{S}^{0}$ were calculated and indicated an endothermic and spontaneous process.
\end{abstract}

Keywords: Castor; Characterization; Lead; Distribution studies; Adsorption isotherms; Thermodynamics

\section{Introduction}

Air Lead $(\mathrm{Pb})$ and its compounds are widely used in industry, hence they are commonly found in air, water, soil, and food[1]. Lead (Pb) may be released into the general environment as a result of automobiles using leaded gasoline as an antiknock agent [2] lead-containing paint [3], water due to lead solder in water pipe systems [3], and atmospheric emissions of lead from industrial sources such as smelters[2].

Some researchers suppose that the use of $\mathrm{Pb}-\mathrm{Bi}$ or $\mathrm{Pb}$ as a coolant in fast reactors could improve NPP reliability due to the elimination of fire hazard [4]. However, when using $\mathrm{Pb}$ or $\mathrm{Pb}-\mathrm{Bi}$, attention should be paid to $\alpha$ radioactivity polonium contamination, produced during reactors operation [4]. The main gamma-emitters in the coolant with operating nuclear reactors are radionuclides of lead: ${ }^{207 \mathrm{~m}} \mathrm{~Pb}$, ${ }^{204 \mathrm{~m}} \mathrm{~Pb}$, and ${ }^{203 \mathrm{~m}} \mathrm{~Pb}$ generated because of threshold nuclear reactions. Lead-204m is of practical importance with activity level $(1-2) \times 10^{7}$ $\mathrm{Bq} / \mathrm{cm}^{3}$ and ${ }^{203} \mathrm{~Pb}$ with activity $(2-5) \times 10^{6}$ $\mathrm{Bq} / \mathrm{cm}^{3}[4]$.

Lead $(\mathrm{Pb})$ is a heavy metal of a great environmental concern and poses threats to plants, animal and human health due to its bioaccumulative tendency and toxicity [5]. Lead has no known beneficial biochemical attribute [6] and it is known to have a toxic effect on the human body causing nausea, encephalopathy, headache, vomiting, learning difficulties, mental retardation, hyperactivity, vertigo, kidney damage, birth defects, muscle weakness, anorexia, cirrhosis of the liver, thyroid dysfunction, insomnia, fatigue, degeneration of motor neurons, and schizophrenic-like behavior are also resulting from lead toxicity [7].

Lead $(\mathrm{Pb})$, being a heavy metal, tends to accumulate in food chain because of its persistent nature, and it is therefore necessary

Corresponding author: ahmhoda@gmail.com

DOI: 10.21608/ajnsa.2018.2340.1026

OScientific Information, Documentation and Publishing Office (SIDPO)-EAEA 
to remove it from waste water [8]. Various treatment techniques have been employed to treat wastewater, such as chemical precipitation, ion exchange, reverse osmosis, electrodialysis, ultrafiltration, nanofiltration, coagulation, flocculation, and floatation, etc.

However these methods have several disadvantages such as high reagent requirement, unpredictable metal ion removal, and generation of toxic sludge etc. An adsorption process being very simple, economical, effective, and versatile has become the most preferred method for removal of toxic contaminants from wastewater [7].

Many researchers are interested in the removal of lead ions from the aqueous wastes using anaerobically digested sludge [9], bacteria [10], fungi [11], algae [12], and others. Agricultural waste materials have also attracted the attention of researchers as biosorbents for the removal of heavy metals in wastewaters [13-16].

The objective of this work is to use castor as a low-cost adsorbent derived from the plant wastes for removing $\mathrm{Pb}^{2+}$ ions from aqueous wastes. The produced adsorbent was characterized using different analytical techniques such as chemical stability, SEM, TGA, XRD analysis, surface area analysis (SSA), and FTIR spectra. The effect of various factors such as contact time, $\mathrm{pH}$, initial metal ion concentration, sorbent amount, particle diameters, competing ions, and temperature on the removal of $\mathrm{Pb}^{2+}$ ions from aqueous wastes was determined. The adsorption isotherm parameters were also calculated and discussed.

\section{Materials and Method}

\section{Chemicals}

Chemicals such as $\mathrm{HCl}, \mathrm{HNO}_{3}$, and $\mathrm{KOH}$ were supplied by Merck as analytical-grade reagents, and de-ionized water was used. Aqueous solutions containing lead $\left(\mathrm{Pb}^{2+}\right)$ at various concentrations were prepared from nitrate lead salt $\left(\mathrm{Pb}\left(\mathrm{NO}_{3}\right)_{2}\right)$. The initial $\mathrm{pH}$ of the solutions was adjusted by adding $\mathrm{HNO}_{3}$. Measurements of the initial $\mathrm{pH}$ of lead ion solutions were carried out using a laboratory pH-meter (model pH 540 GLP) equipped with a combined glass electrode (SENTIX 41). A preliminary calibration is systematically carried out using suitable buffer solutions.

\section{Preparation of the sorbent}

The sorbent material was prepared from castor stem which was dried at $110 \pm 5^{\circ} \mathrm{C}$, then the material was grinded. Castor stem is immersed in $1 \mathrm{M}$ potassium hydroxide with heating at $85 \pm 2^{\circ} \mathrm{C}$ for 2 hours, the mixture was left for one day, then washed several times with distilled water until $\mathrm{pH}$ became 6.5. The sorbent material was left in air to dry then immersed in $4 \mathrm{M}$ hydrochloric acid. The castor stem washed by distilled water several times until the $\mathrm{pH}$ became 5 then left it in air to dry and finally grinded.

\section{Characterization of castor sorbent}

Particle size was determined using sieves of different particle sizes. Packed and apparent densities were determined by a tamping procedure using a $25 \mathrm{~mL}$ graduated glass cylinder. The sorbent was analyzed for their BET-specific surface area using Quantachrome NovaWin - Data Acquisition and Reduction for NOVA instruments (C)1994-2013, Quantachrome Instruments version 11.03 (calculated using the BET standard method). The XRD spectra of the powdered sample was carried out using a Shimadzu X-ray diffractometer obtained from Shimadzu Kyoto "Japan", model $\mathrm{XD}-\mathrm{Dl}$, with a nickel filter and a $\mathrm{Cu} \mathrm{K}_{\alpha}-\mathrm{X}$-ray tube $(\lambda=1.5418 \AA)$, in a diffraction angle $(2 \theta)$ range of $4^{\circ}-90^{\circ}$. SEM image of the particles was identified using Jeol scanning electron microscope of JSM6510A Model, Japan, operating with beams of primary electrons ranging from 5 to $10 \mathrm{keV}$. The chemical composition of the studied sorbent was performed by Flash EA Analyzer, Italy (Elemental analysis, $\mathrm{C}, \mathrm{H}$, and $\mathrm{N}$ concentrations). The IR spectrum of the castor sorbent was measured by the $\mathrm{KBr}$ disc method by mixing of the solid with potassium bromide in ratio 1:4 and ground to a very fine powder. A transparent disc was formed in a moisture free atmosphere. The IR spectrum was recorded using a Shimadzu infrared spectrometer (BOMEM-FTIR) obtained from Shimadzu Kyoto "Japan", in the range 400-4000 $\mathrm{cm}^{-1}$. Measurements of thermogravimetric analysis (TGA) were carried out using a Shimadzu DTG$60 / 60 \mathrm{H}$ thermal analyzer obtained from Shimadzu Kyoto "Japan". The sample was measured from ambient temperature up to $1000^{\circ} \mathrm{C}$ in $\mathrm{N}_{2}$ 
atmosphere, with a heating rate of $10^{\circ} \mathrm{C} / \mathrm{min}$ and using alumina powder as a reference material.

\section{Batch adsorption studies}

Some experimental conditions such as effect of solution $\mathrm{pH}$, contact time, sorbent amount, adsorption temperature, initial ion concentrations, and interfering ions, on adsorption of $\mathrm{Pb}^{2+}$ ions were studied. For each experiment run, $0.05 \mathrm{~g}$ of castor was contacted with $5 \mathrm{~mL}$ of $\mathrm{Pb}^{2+}$ ions solution at a $\mathrm{V} / \mathrm{m}$ ratio of $100 \mathrm{~mL} \cdot \mathrm{g}^{-1}$ at a shaking speed of $400 \mathrm{rpm}$ for $4 \mathrm{~h}$ was performed. The effect of solution $\mathrm{pH}$ on the equilibrium adsorption of the studied metal ions was investigated under similar experimental conditions at range of $\mathrm{pH} 1$ to 5. The $\mathrm{pH}$ of the solutions was adjusted using solution of nitric acid and was measured before and after equilibration. The influence of contact time on batch experiments was examined by varying the contact time from 10 to $1440 \mathrm{~min}$. The sorbent amounts used were varied between 0.005$0.2 \mathrm{~g} / 5 \mathrm{~mL}$ with an initial concentration of 50 mg. $\mathrm{L}^{-1}$ of the above mentioned metal ions solutions. The effect of initial ion concentrations was examined by varying the initial metal ion concentrations from 50 to $500 \mathrm{mg} . \mathrm{L}^{-1}$. The adsorption temperature effect was carried out on the prepared sorbent at 25,45 , and $65 \pm 1^{\circ} \mathrm{C}$. After equilibrium, the solutions were separated by centrifugation. The adsorption percentage (U\%) of metal ions by solid phase was deduced as in equation 1 . The concentration of the metal ions was measured using atomic absorption spectrophotometer $(A A S)$. All tests were repeated for three times and the total experimental error was found to be about $\pm 3 \%$.

$U(\%)=\frac{A_{o}-A_{f}}{A_{o}} \times 100$
$K_{d}(m L / g)=\frac{\left[A_{o}-A_{f}\right]}{A_{f}} \times \frac{V}{m}$

where $K_{d}$ is the distribution coefficient, $A_{o}$ and $A_{f}$ are the concentrations of the ions in solution before and after equilibration (mg. $\mathrm{L}^{-1}$ ), respectively, $\mathrm{V}$ is the solution volume $(\mathrm{mL})$, and $\mathrm{m}$ is the exchanger mass (g).

\section{Adsorption isotherm experiments}

The adsorption isotherms were done by a gradual increase in the concentration of the sorbate ions in solution and measuring the amount sorbed at each equilibrium concentration. The degree of adsorption should, therefore, be a function of the concentration of sorbet ions only. The adsorption isotherms were investigated for $\mathrm{Pb}^{2+}$ in the concentration range from 50 to $500 \mathrm{mg} \cdot \mathrm{L}^{-1}$ at a constant $\mathrm{V} / \mathrm{m}$ value of $100 \mathrm{~mL} \cdot \mathrm{g}^{-1}$. After equilibration, the respective mixture was filtered, and then the filtrate was measured using atomic absorption spectrophotometer.

\section{Results and Discussion}

\section{Characterization of castor sorbent}

The physico-chemical characterization and chemical composition of the studied sorbent are shown in Table (1).

The selective FTIR bands of castor sorbent are shown in Figure (1). The broad peak at $3420 \mathrm{~cm}^{-1}$ represents stretching vibration mode of hydroxyl groups [17]. The two peaks at 2925 and $2847 \mathrm{~cm}^{-1}$ related to asymmetric and symmetric $\mathrm{C}-\mathrm{H}$ stretching vibration mode of methylene group in aliphatic components [18,19]. The peak at 1593 $\mathrm{cm}^{-1}$ represents $\mathrm{C}=\mathrm{C}$ stretching of aromatic ring [17]. The peaks at 1421,1401 , and $1376 \mathrm{~cm}^{-1}$ resulting from deformation vibration of $\mathrm{CH}_{2}$ and bending of $\mathrm{C}-\mathrm{H}$ group in aliphatic components [17-20].

Table (1) Physical characteristics and chemical composition of castor sorbent

\begin{tabular}{lc}
\hline Parameter & Value \\
\hline C\% & 62.01 \\
H\% & 4.15 \\
N\% & 6.13 \\
Moisture content $(\%)$ & 6.60 \\
Bulk density $(\mathrm{g} / \mathrm{mL})$ & 0.250 \\
Apparent density $(\mathrm{g} / \mathrm{mL})$ & 0.156 \\
Ash content $(\%)$ & 1.32 \\
pH & 5.00 \\
Surface area $\left(\mathrm{m}^{2} / \mathrm{g}\right)$ & 4.35 \\
Particle size $(\mu \mathrm{m})$ & $168-750$ \\
\hline
\end{tabular}




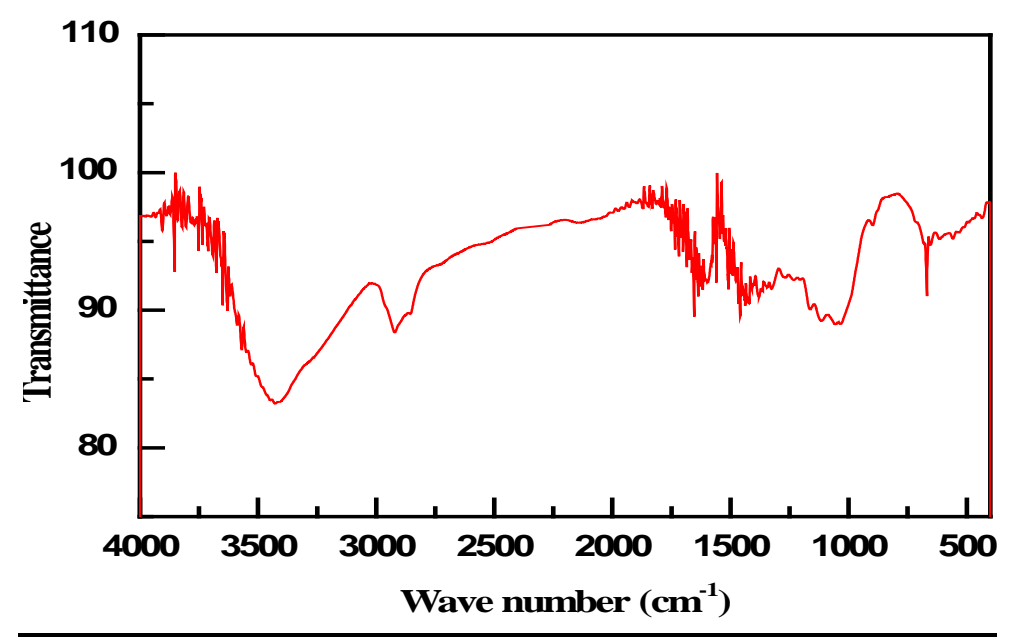

Figure (1) The IR spectrum of castor sorbent

The peak at $1323.50 \mathrm{~cm}^{-1}$ represents the symmetric stretching vibration mode of COO-[21]. The peak at $1233 \mathrm{~cm}^{-1}$ represents $\mathrm{C}-\mathrm{O}$ stretching of ether linkage. The peak at $1160 \mathrm{~cm}^{-1}$ represents the C$\mathrm{O}-\mathrm{C}$ asymmetric bridge stretching vibration mode [17]. The peak at $1106 \mathrm{~cm}^{-1}$ represents $\mathrm{O}-\mathrm{H}$ bending deformation vibration mode of alcoholic, phenolic, and carboxylic groups [22]. The peak at $1025 \mathrm{~cm}^{-1}$ represents the $\mathrm{C}-\mathrm{OH}$ stretching vibration mode due to several groups at the surface of the biomass [21]. In general, the peaks present from 1000-1100 resulting from the presence of polysaccharides [23]. Bands presented between 900-700 $\mathrm{cm}^{-1}$ related to $\mathrm{C}-\mathrm{H}$ out of plane bending deformation in aromatic structure [24]. The peaks present between $700-400 \mathrm{~cm}^{-1}$ may be resulting from stretching mode of $\mathrm{C}-\mathrm{C}$ bond [17] or $\mathrm{O}-\mathrm{H}$ bending deformation in aromatic system [22]. XRD spectrum of the powdered sample is shown in Figure (2), the XRD pattern of castor sorbent showed typical spectrum of cellulosic material having the peaks at $16.5^{\circ}$ and $22.4^{\circ}$, which indicates the presence of highly organized crystalline cellulose [25], while another peak observed at $34^{\circ}$ that could be attributed to presence of less organized polysaccharide structure [26].

Thermogravimetric analysis (TGA) results for castor sorbent is presented in Figure (3), there is a loss of initial mass of about $6.60 \%$ equivalent to water and volatile material losses from the sample. The second loss of mass of about $67.08 \%$ which corresponding to the burning of organic material Scanning electron microscope (SEM) is presented in Figure 4. From which, it was noticed that the castor sorbent material formed of arranged and (hemicellulose and most of cellulose) begins at approximately $240^{\circ} \mathrm{C}$ and extends up to $376{ }^{\circ} \mathrm{C}$ [27]. A third weight loss occurred approximately from $377^{\circ} \mathrm{C}$ to $527^{\circ} \mathrm{C}$ which results from the decomposition of lignin [28].

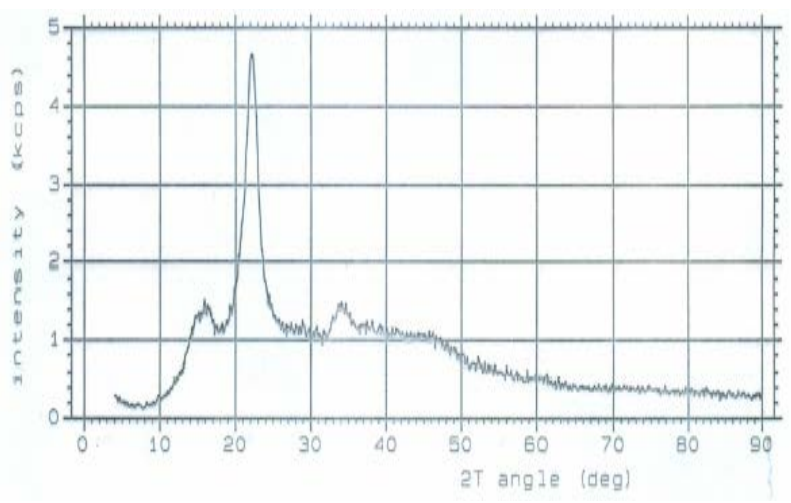

Figure (2) XRD diagrams of castor sorbent (asprepared)

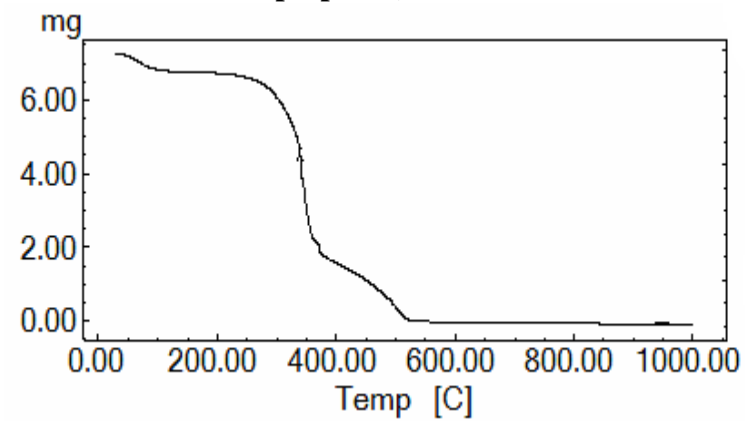

Figure (3) Thermogravimetric analysis (TGA) of castor sorbent (as-prepared)

highly condensed fibers forming plates due to the presence of highly organized cellulosic material and appearance of a visible separation between 
fibers which caused by treatment of the castor material. Dispersed particles are noticed due to lignin materials or another polysaccharide material and also some cavities or gaps appear which result from the modification of castor sorbent [17].

\section{Factors affecting adsorption of $\mathrm{Pb}^{2+}$ ions onto} castor sorbent

Effect of concentration

The effect of concentration of $\mathrm{Pb}^{2+}$ ions has been tested with constant amount of adsorbent $0.05 \mathrm{~g} /$ $5 \mathrm{~mL}$ as shown in Figure (5). The removal of $\mathrm{Pb}$ (II) ions decreased from 94 to 63\% with increasing the lead ion concentration from 50 to $500 \mathrm{mg} \cdot \mathrm{L}^{-1}$. The results indicated that the adsorption of $\mathrm{Pb}^{2+}$ is

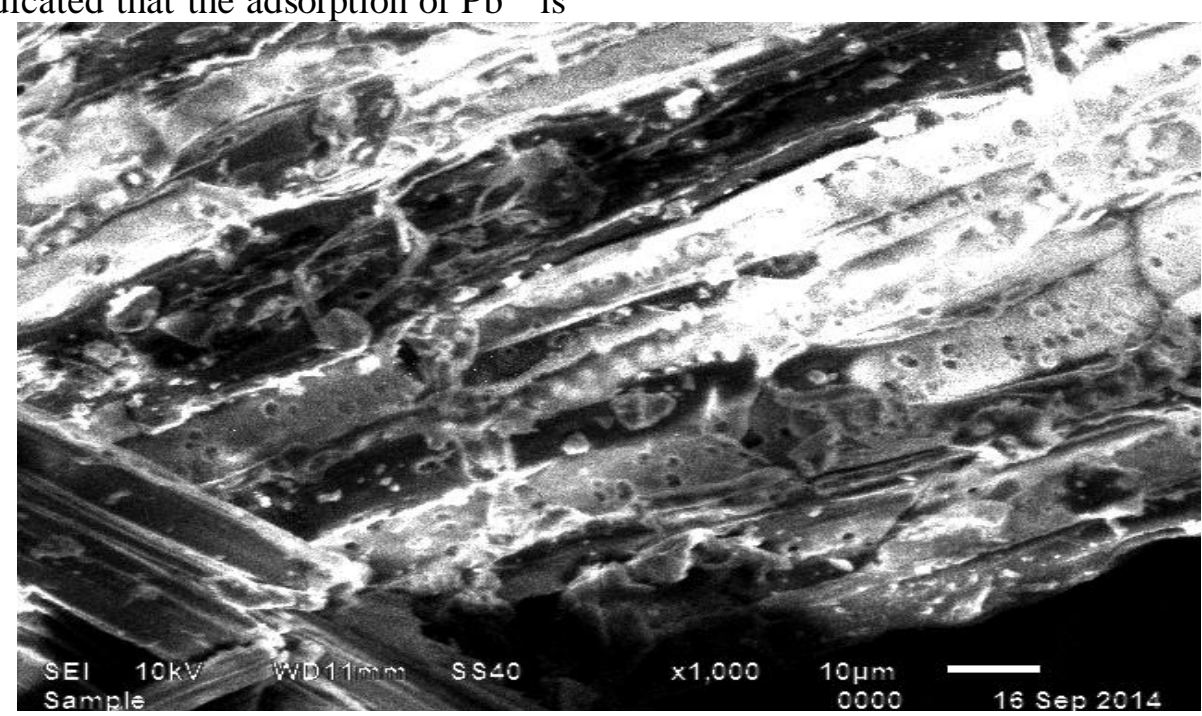

Figure (4) Scanning electron microscope (SEM) of castor sorbent (as-prepared)

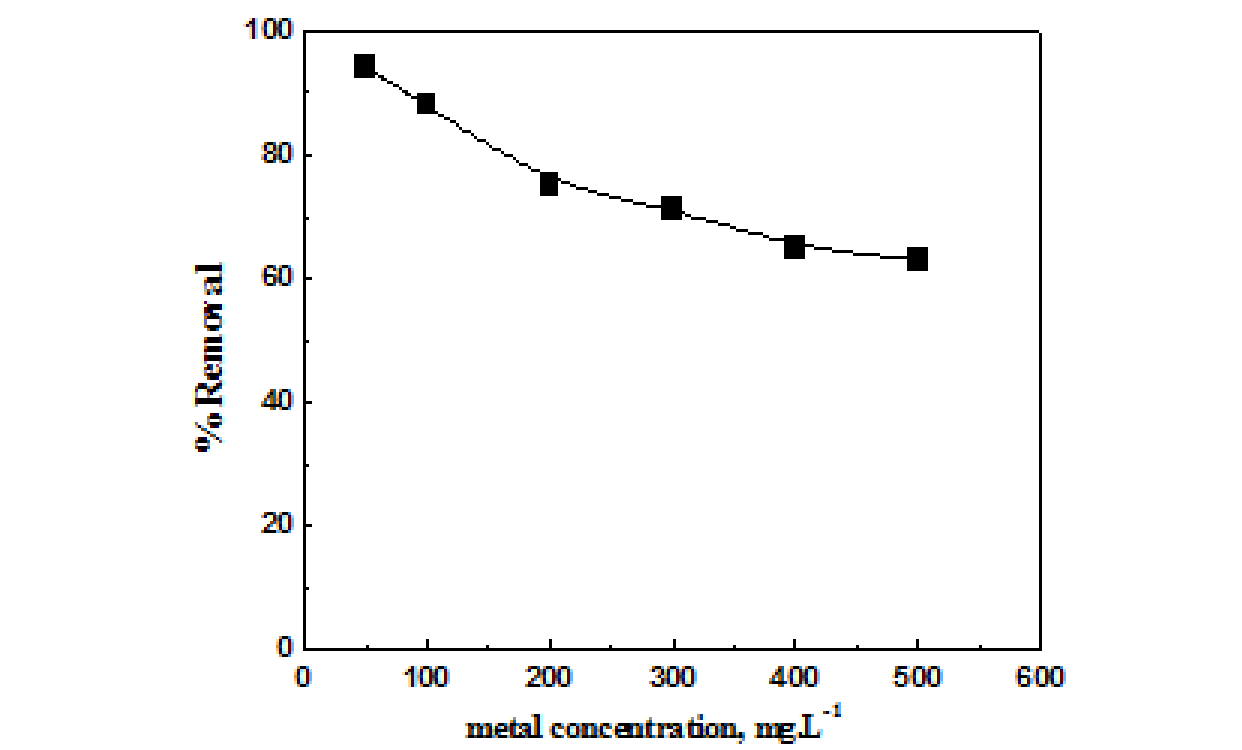

Figure (5) Effect the metal concentration of $\mathrm{Pb}^{2+}$ on the adsorption onto castor sorbent at pH5 much dependent on its concentration of solution. These observations are in close agreement with those reported in previous studies [22, 29-33]. The decrease in removal efficiency with increasing the initial concentration of $\mathrm{Pb}^{2+}$ ions may be resulting from that increasing the ion concentration of metal ions with a fixed amount of sorbent give a limited available number of active sites thereby adsorbing almost the same amount of adsorbate, this result causes a decrease in the removal percentage of adsorbate corresponding to an increase in the initial ion concentration [34]. 


\section{Effect of contact time}

Contact time is one of the important parameters for successful employment of the sorbents for practical application. Adsorption experiments were carried out for different contact times with a fixed adsorbent amount of $0.05 \mathrm{~g} / 5 \mathrm{~mL}$ at $\mathrm{pH} 5$. The experimental results demonstrate the effect of contact time as shown in Figure (6). The results show that the equilibrium of $\mathrm{Pb}$ (II) ions reaches after 4 hours. A higher adsorption rate occurs due to the greater of vacant sites on castor surface in the beginning of adsorption process, hence strong attractive forces between $\mathrm{pb}^{2+}$ ions and castor sorbent are observed [35]. Then the number of vacant sites decreases which resulting the decrease in the adsorption rate. Finally the curve became parallel to the $\mathrm{X}$-axis, this point to reaching to the equilibrium of castor sorbent with lead ions. So, as the contact time increases the uptake value increases and then, the active site on the sorbent were filled and the rate of adsorption reached constant value.

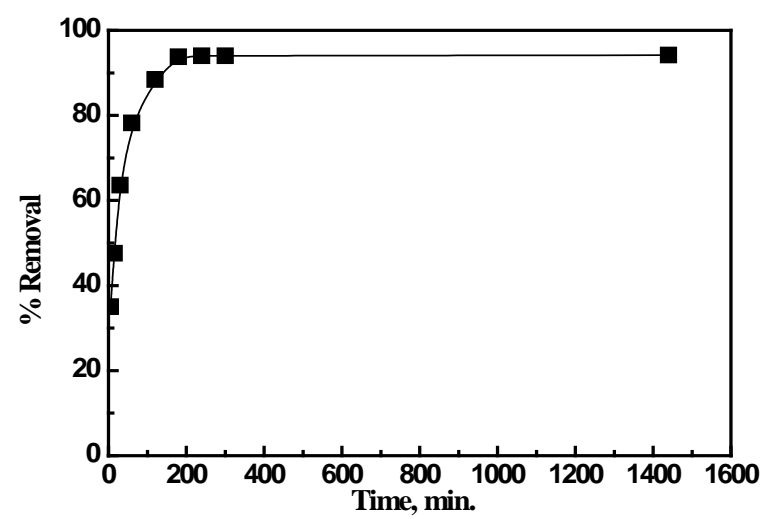

Figure (6) Effect of contact time on the adsorption of $\mathrm{Pb}^{2+}$ ions from aqueous solution at $\mathrm{pH} 5$ using castor sorbent

\section{Effect of sorbent amount}

The effect of the amount of selected sorbent was studied by varying the sorbent amount from 0.005 to $0.2 \mathrm{~g}$. From Figure (7), it could be observed that the amount of sorbent was found to have effect on sorbent capability in removing $\mathrm{pb}^{2+}$ ions from aqueous solution. An increase in the removal percentage of $\mathrm{Pb}^{2+}$ ions was noticed with increasing the amount of sorbent. This happens due to the greater availability of surface area of the sorbent and also increasing the number of active sites on the sorbent surface which leads to increasing the removal of $\mathrm{Pb}^{2+}$ ions [36]. However, further increasing above $0.05 \mathrm{~g}$ in the sorbent amount did not make any significant change in the removal percentage of lead ions. A further increase in the sorbent amount leads to an increase in the number of active sites with a limited number of sorbate of lead ions. The sorbate is removed until it reaches the equilibrium stage and then no more lead ions could be removed [37].

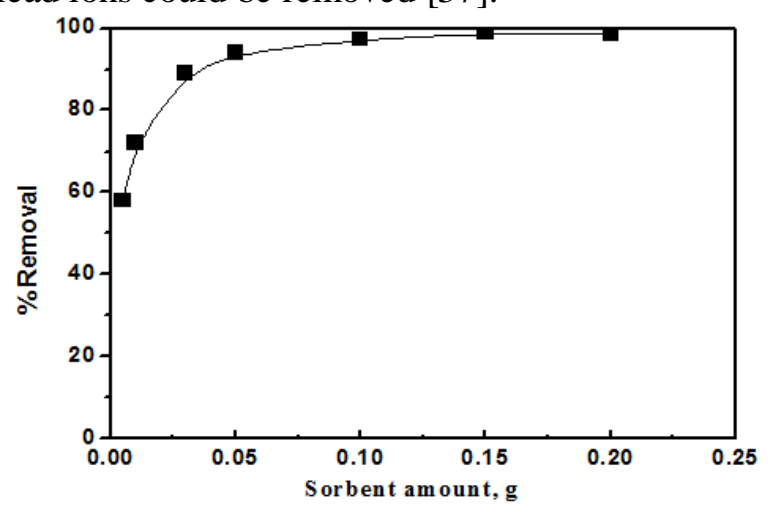

Figure (7) Effect the castor sorbent amount on the adsorption of $\mathrm{Pb}^{2+}$ from aqueous solution at $\mathrm{pH} 5$

\section{Effect of particle size}

The sorbent particle size is an important factor in adsorption process. The effect of particle size on the adsorption of $\mathrm{Pb}^{2+}$ ions was studied by conducting a series of experiments with different particle sizes ranging from 231-1000 $\mu \mathrm{m}$. Figure (8) shows that the removal of $\mathrm{Pb}^{2+}$ ions increases with decreasing the particle size of the sorbent. The greater uptake at smaller particle size is due to the fact that the smaller particles move faster in solution than the large particles. Moreover the increasing in surface area due to small particle size also increases the number of sites, and directly increases the removal valuen [38].

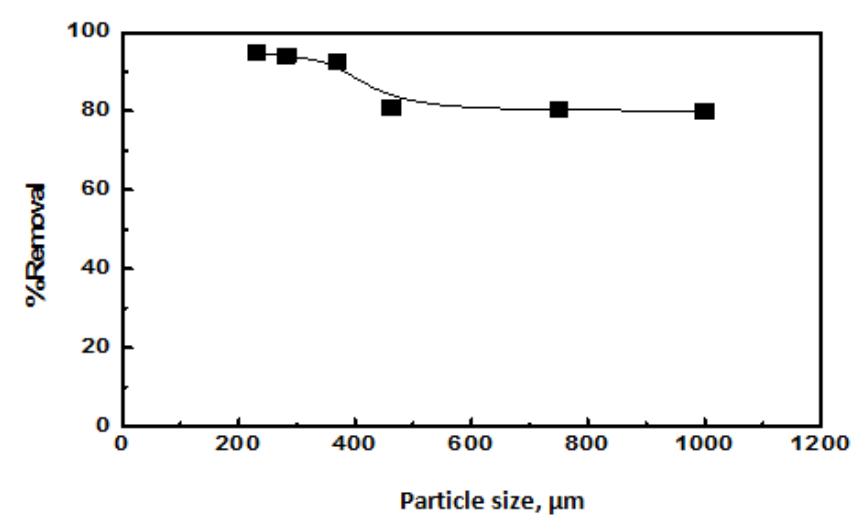

Figure (8) Effect of particle size on the adsorption of $\mathrm{Pb}^{2+}$ from aqueous solution using castor sorbent at $\mathrm{pH} 5$ 


\section{Effect of interfering ions}

The effect of competing cations such as sodium and complexing agent (EDTA) on the adsorption of $\mathrm{Pb}^{2+}$ ions on castor sorbent is presented in Figure (9). The influence of various concentrations of $\mathrm{Na}^{+}$and EDTA $\left(10^{-4}-0.1 \mathrm{M}\right)$ on the removal of $\mathrm{Pb}^{2+}$ ions on castor sorbent was studied. The presence of sodium ions or EDTA complexing agent with $\mathrm{Pb}^{2+}$ ions leads to decreasing the removal percentage of lead ions using castor sorbent. Increasing of sodium and EDTA concentrations causes a further decrease in the removal percentage of lead ions. The presence of a low concentration of a chelating agent EDTA which makes a chelation with lead ions to form metal complex which leads to a sudden decrease in the free lead metal ions concentration in the solution so the decreasing of the removal percentage of $\mathrm{Pb}$ (II) ions using castor occurred [39- 40].

Increasing $\mathrm{Na}^{+}$ions in the $\mathrm{Pb}^{2+}$ ions solution leads to a gradual decrease in the removal percentage of $\mathrm{Pb}$ (II) ions, because of the competing between lead and sodium ions on the active sites of castor sorbent and repulsion force which initiate between lead and sodium ions [13].

\section{Effect of solution $\mathrm{pH}$}

The effect of the solution $\mathrm{pH}$ on the adsorption of $\mathrm{Pb}^{2+}$ ions on castor sorbent is shown in Figure (10). The $\mathrm{pH}$ range was adjusted from 1 to 5 . This range was chosen to avoid metal solid hydroxide precipitation. From Figure (10), it was noticed that a very small removal percentage value at low $\mathrm{pH}$, a significant enhancement in $\mathrm{Pb}^{2+}$ ions removal is recorded when the $\mathrm{pH}$ of the system increases. At low $\mathrm{pH}$, the sorbent surface has a positive charge, so the smaller adsorption values can be attributed to the repulsion between the same charge of the cation and the sorbent and also due to the competition between the hydrogen and lead ions in highly acidic media. Increasing $\mathrm{pH}$ values, a negative charge density on the surface increases due to successive deprotonation of positive charged groups and unprotonated carboxylic groups on the surface of castor sorbent and also low $\mathrm{H}^{+}$ion concentration. So the electrostatic attraction between the negatively charged sites of the adsorbent and the positively charged cation rise so the removal of lead ions from the solution increased [41- 44].

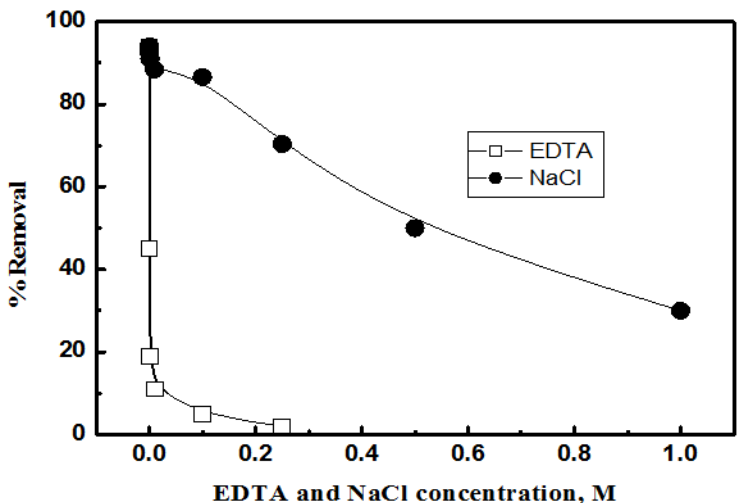

Figure (9) Effect of different concentrations of EDTA and $\mathrm{NaCl}$ on the adsorption of $\mathbf{P b}^{2+}$ ions from aqueous solution at pH 5 using castor sorbent

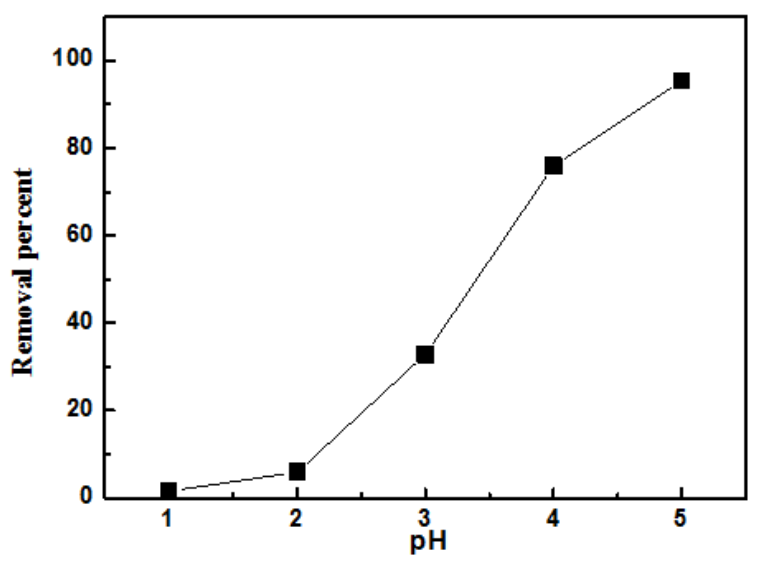

Figure (10) the effect of $\mathrm{pH}$ on the removal percent of lead ions using castor sorbent.

\section{Adsorption isotherm}

Adsorption isotherm is an invaluable curve describing the phenomenon governing the mobility of the ions from aqueous media to the solid phase at constant temperature and $\mathrm{pH}$. Adsorption models describe the surface properties, adsorption mechanism, and the affinity of the sorbent. Experimental data obtained from the effect of the initial concentration of sorbate on the adsorption capacity of sorbent were evaluated with the two popular adsorption models which are Langmuir and Freundlich models.

\section{Langmuir isotherm}

Langmuir model describes the homogeneous adsorption surface. It assumes monolayer adsorption, adsorption could occur at a fixed number of definite sites. These sites are identical equivalent energetically with no interaction and steric hindrance between the adsorbed molecules, even on adjacent sites. The linear formula of Langmuir equation is given as [45]: 


$$
\frac{C_{e}}{a_{e}}=\frac{1}{b Q}+\frac{C_{e}}{Q}
$$

where $C_{e}\left(m g . L^{-1}\right)$ is the equilibrium concentration of the adsorbate ions, $\mathrm{q}_{\mathrm{e}}$ is the amount of ions sorbed per gram of sorbent (mg.g ${ }^{-1}$ ) at equilibrium, while Q and $\mathrm{b}$ are Langmuir constants related to maximum adsorption capacity (monolayer capacity) (mg. $\mathrm{g}^{-1}$ ) and the heat of adsorption $\left({\mathrm{L} . \mathrm{mg}^{-1}}^{-1}\right.$, respectively.

Plotting of $\mathrm{C}_{\mathrm{e}} / \mathrm{q}_{\mathrm{e}} \mathrm{vs}$. $\mathrm{C}_{\mathrm{e}}$, gives linear relationships with correlation coefficient $\mathrm{R}^{2}=0.966$, as shown in Figure 11. From the slope and intercept of this linear plot, the value of Langmuir constants $Q$ and $\mathrm{b}$ are calculated and summarized in Table (2).

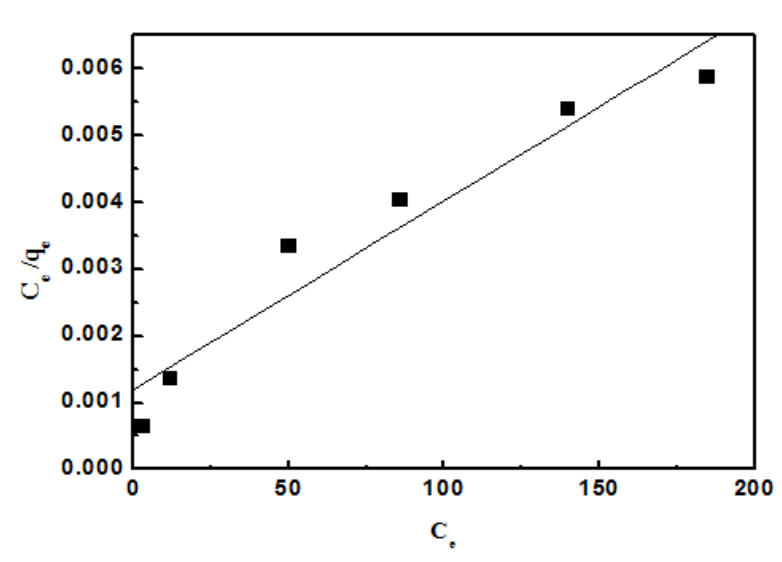

Figure (11) Linearized Langmuir isotherm model for the adsorption of $\mathbf{P b}^{2+}$ ions on castor sorbent

Table (2) Parameters of Langmuir and Freundlich isotherms for adsorption of Pb (II) on castor sorbent

\begin{tabular}{ccccccc}
\hline Cation & \multicolumn{2}{c}{ Langmuir constants } & \multicolumn{2}{c}{ Freundlich constants } \\
\cline { 2 - 7 } & $\mathrm{Q}\left(\mathrm{mg} \cdot \mathrm{g}^{-1}\right)$ & $\mathrm{b}\left(\mathrm{L} \cdot \mathrm{mg}^{-1}\right)$ & $\mathrm{R}^{2}$ & $\mathrm{~K}_{\mathrm{f}}\left(\mathrm{mg} \cdot \mathrm{g}^{-1}\right)$ & $1 / \mathrm{n}$ & $\mathrm{R}^{2}$ \\
\hline $\mathrm{Pb}^{2+}$ & 35,48 & 0.023 & 0.966 & 2.75 & 0.450 & 0.997
\end{tabular}

Freundlich isotherm model

The Freundlich model is applicable for non ideal and reversible adsorption on heterogeneous surface and multilayer adsorption. The linear form of Freundlich model is [46].

$$
\log q_{e}=\log K_{f}+(1 / n) \log C_{e}
$$

where $K_{f}$ represents the adsorption capacity when the metal equilibrium concentration equal to 1 and $1 / n$ represents the heterogeneity factor which determines the bond distribution. $K_{f}$ and $n$ are determined from the intercept and slope of plot between $\log \mathrm{q}_{\mathrm{e}}$ and $\log \mathrm{C}_{\mathrm{e}}$.

The relation between $\log q_{e}$ and $\log C_{e}$ is presented in Figure (12) giving a straight line relationship with correlation coefficient $\mathrm{R}^{2}=0.997$, Freundlich constants are summarized in Table (2), and the values of $1 / n$ is 0.450 , smaller than one $(0<1 / n<1)$, which implies heterogeneous surface structure and favorable Freundlich adsorption processes [47]. From the above studies, the results suggest that the adsorption of the studied metal ions on castor is favorable for the Freundlich isotherm more than Langmuir isotherm for the following reasons:
1- The correlation coefficient $\mathrm{R}^{2}$ represented Freundlich isotherm for the studied metal ions is greater than of Langmuir isotherm.

2- The numerical values of $1 / \mathrm{n}$ for the studied metal ion were found to be ranging between 0 and $1(0<1 / \mathrm{n}<1)$ Table (2); this implies a heterogeneous surface structure and favorable Freundlich adsorption processes.

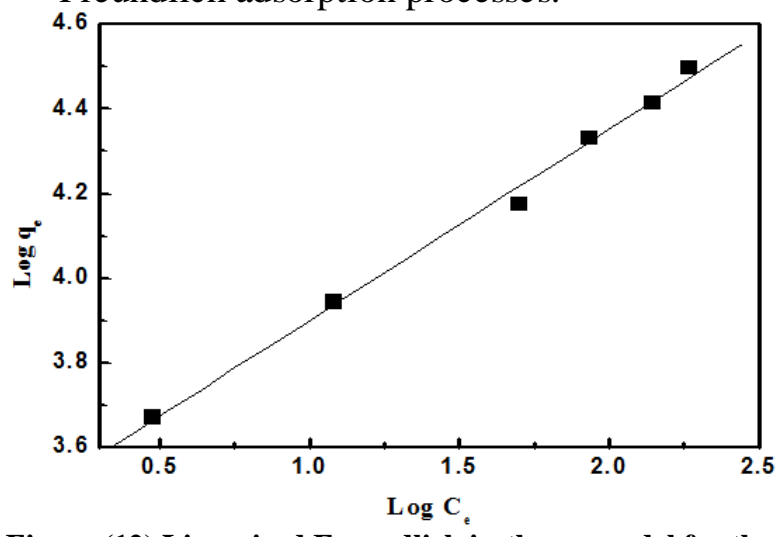

Figure (12) Linearized Freundlich isotherm model for the adsorption of $\mathbf{P b}^{2+}$ ions on castor sorbent 


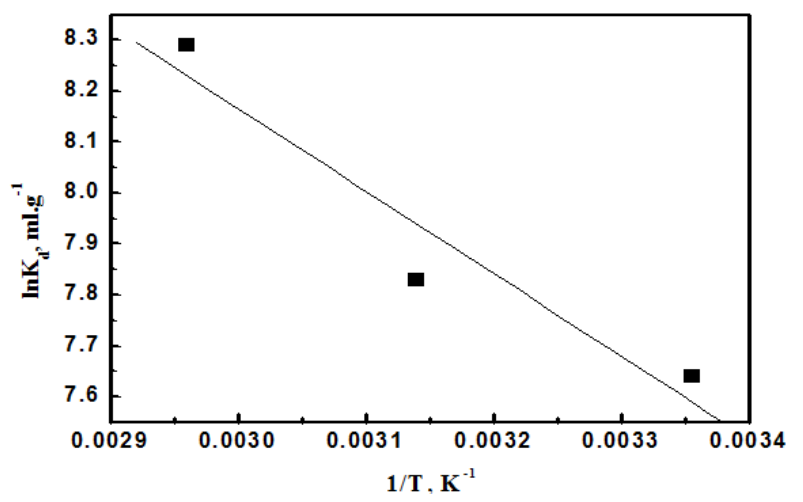

Figure (13) Van,t Hoff plot of the adsorption of Pb2+ ions by castor sorbent

Adsorption thermodynamics

Thermodynamic parameters such as $\left(\Delta \mathrm{H}^{\circ}\right)$ and $\left(\Delta S^{\circ}\right)$ were obtained from the following Van't Hoff equation:

$L n K_{d}=\frac{\Delta S^{o}}{R}-\frac{\Delta H^{o}}{R T}$

Where $\Delta \mathrm{So}(\mathrm{J} / \mathrm{mol} . \mathrm{oK})$ is the standard entropy change, , $\Delta \mathrm{H}^{\circ}(\mathrm{kJ} / \mathrm{mol})$ is the standard enthalpy change, and $\mathrm{R}\left(8.314 \mathrm{~J} / \mathrm{mol} .{ }^{\circ} \mathrm{K}\right)$ is the gas constant, and $\mathrm{T}\left({ }^{\circ} \mathrm{K}\right)$ is the absolute temperature. From Figure 13 , the $\Delta H^{0}$ and the $\Delta S^{0}$ values could be calculated from the slope $\left(-\Delta \mathrm{H}^{\circ} / \mathrm{R}\right)$ and intercept $\left(\Delta \mathrm{S}^{\circ} / \mathrm{R}\right)$ of the linear plot of $\ln K_{d}$ versus $1 / T$. The thermodynamic parameter, $\left(\Delta G^{0}\right)$ was calculated using the relation:

$\Delta G^{o}=-R T \ln K_{d}$

Where $\Delta \mathrm{G}^{\circ}(\mathrm{kJ} / \mathrm{mol})$ is the standard free energy change. Values of these parameters are listed in Table (3). The positive value of $\Delta \mathrm{H}^{0}$ showed that the adsorption was endothermic in nature, while the positive values of $\Delta S^{\circ}$ indicates that there is an increase in the randomness at solid /solution interface during the adsorption of $\mathrm{Pb}^{2+}$ ions on castor sorbent [48- 50]. Values of $\Delta G^{\circ}$ are negative, confirming that the adsorption of $\mathrm{Pb}$ (II) ions onto castor sorbent is spontaneous and thermodynamically favorable [48- 50]. The more negative values of $\Delta G^{0}$ imply a greater driving force to the adsorption process [22].

A comparison of sorption capacity of $\mathrm{Pb}(\mathrm{II})$ ions onto castor with other sorbents

The adsorption capacities of different adsorbents derived from agriculture residues are given in Table (4) for the comparison of capacity of lead ions onto castor with other sorbent. Some of sorbents have sorption capacity more than castor as shown in Table (4). The cost of sorbent is also an important issue that must be considered when selecting a sorbent. Caster can be considered as low-cost material for removal of $\mathrm{Pb}$ (II) ions from waste solution.

\section{Application}

The application to a real sample is one of the most important factors should be considered for any solid phase used as adsorbent in the removal of any pollutant(s). Castor contains different functional groupings which are capable of sorbing $\mathrm{pb}$ (II) from aqueous wastes. This real sample was collected from battery factories in 10th of Ramadan, Egypt. The sample was bottled in a plastic container and was immediately taken to the laboratory for analysis. The $\mathrm{pH}$ of the sample was about 3. AAS was used for analyzing the sample, the heavy metals present in this real sample were $\mathrm{Cu}^{2+}, \mathrm{Cd}^{2+}, \mathrm{Ni}^{2+}$, and $\mathrm{Pb}^{2+}$ their concentrations was shown in Table (5). The sample was spiked with castor (spiking with $0.01 \mathrm{~g} / \mathrm{mL}$ ). As shown in Table (5), the removal efficiencies of castor are about $12 \%, 9 \%$, 3\%, and 90 for $\mathrm{Cu}^{2+}, \mathrm{Cd}^{2+}, \mathrm{Ni}^{2+}$, and $\mathrm{Pb}^{2+}$, respectively. The results indicated that castor is a good adsorbent for the removal of $\mathrm{Pb}$ (II) from heavy metals wastewater and confirmed the validity of the proposed method for real samples. The attractive features of castor are that it is commercially available, effective, and of low-cost.

Table (3) Thermodynamic parameters for adsorption of $\mathrm{Pb}^{2+}$ ions by castor sorbent at different reaction temperatures

\begin{tabular}{|c|c|c|c|}
\hline \multirow[b]{2}{*}{$\begin{array}{c}\text { Temperatures, } \\
\left({ }^{\circ} \mathrm{C}\right)\end{array}$} & \multicolumn{3}{|c|}{ Thermodynamic parameters } \\
\hline & $\begin{array}{c}\Delta \mathbf{H}^{0}, \\
(\mathrm{~kJ} \cdot \mathrm{mo} \\
\left.\mathrm{l}^{-1}\right)\end{array}$ & $\begin{array}{c}\Delta G^{0}, \\
\left(\begin{array}{c}\left.\mathbf{k J}^{-1}\right) \\
\text { (mo }\end{array}\right.\end{array}$ & $\begin{array}{c}\Delta \mathbf{S}^{\mathbf{0}}, \\
\left(\mathrm{J} \cdot \mathrm{mol}^{-1} \cdot \mathrm{K}^{-1}\right)\end{array}$ \\
\hline 298 & \multirow{3}{*}{13.47} & -18.93 & \multirow{3}{*}{108.33} \\
\hline 318 & & -20.70 & \\
\hline 338 & & -23.32 & \\
\hline
\end{tabular}


Table (4) Adsorption capacities (mg/g) of $\mathrm{Pb}(\mathrm{II})$ with different adsorbents

\begin{tabular}{lcc}
\hline \multicolumn{1}{c}{ Adsorbent } & $\mathrm{Pb}(\mathrm{II})$, Capacity $\left(\mathrm{mg} \mathrm{g}^{-1}\right)$ & References \\
\hline Coffee residue activated carbon & 63.00 & {$[51]$} \\
Sawdust & 3.19 & {$[1]$} \\
Algal biomass (Oedogonium sp. and & 145.00 & {$[52]$} \\
$\quad$ Nostoc sp.) & & \\
Coconut shell activated carbon & 26.50 & {$[53]$} \\
Crushed concrete fines & 37.00 & {$[54]$} \\
Peels of banana & 2.18 & {$[55]$} \\
Amanita rubescens biomass & 38.4 & {$[56]$} \\
Fruit shell (Mangostana) & 3.56 & {$[57]$} \\
Saccharomyces cerevisiae biomass & 83.33 & {$[58]$} \\
Leucaena activated carbon & 15.09 & {$[59]$} \\
Castor & 35.48 & {$[$ Current work] } \\
\hline
\end{tabular}

Table (5) Initial concentration of metal ions in wastewater

\begin{tabular}{lll}
\hline Heavy metals & Initial concentration (mg/L) & Removal (\%) \\
\hline $\mathrm{Cu}^{2+}$ & 14 & 12 \\
$\mathrm{Cd}^{2+}$ & 8 & 9 \\
$\mathrm{Ni}^{2+}$ & 25 & 3 \\
$\mathrm{~Pb}^{2+}$ & 3 & 90 \\
\hline
\end{tabular}

\section{Conclusion}

In this work, castor was used as one of the natural sorbent derived from agriculture waste. The produced sorbent is a crystalline material. The removal of lead ions using castor sorbent increased with increasing the $\mathrm{pH}$, contact time, castor sorbent amount, and reaction temperature, but the removal percentage decreased with increasing the lead ions concentration, particle size, and interfering ions (EDTA- $\mathrm{Na}^{+}$). Adsorption data was more fitted to Freundlich model than Langmuir model. The thermodynamic results indicate an endothermic and spontaneous process. Castor is a good adsorbent for the removal of $\mathrm{Pb}(\mathrm{II})$ from heavy metals wastewater and confirmed the validity of the proposed method for real samples.

\section{References}

1- Yu B, Zhang Y, Shukla A, Shukla S S, and Dorris $\mathrm{K} \mathrm{L}$. The removal of heavy metals from aqueous solutions by sawdust adsorption-removal of lead and comparison of its adsorption with copper. $J$. Hazard. Mater. B84, 83-94 (2001).

2- USEPA. Air Quality Criteria for Lead Vols I-IV EPA 600/8-83/02a F.Washington, DC: US Environmental Protection Agency. (1986).

3- NAS/NRC. Measuring Lead in Exposure in Infants, Children, Other Sensitive Populations. Washington, DC: National Academies Press.; 337 (1993).

4- International Atomic Energy Agency. Liquid Metal Coolants For Fast Reactors Cooled By Sodium, Lead, And Lead-Bismuth Eutectic, IAEA Nuclear Energy Series No. NP-T-1.6, IAEA, VIENNA (2012) .

5- Horsfall M, and Spiff A I. Studies on the effect of $\mathrm{pH}$ on the sorption of $\mathrm{Pb}^{2+}$ and $\mathrm{Cd}^{2+}$ ions from aqueous solutions by Caladium bicolor (wild cocoyam) biomass. Electron. J. Biotechnol.; 7 (3) December 15 Issue (2004).

6- Harrison R M, DE Mora S J, Rapsomanikis S, Johnston W R. (1993) Introductory chemistry for environmental sciences. University Press: Cambridge, 35 (1993).

7- Lakherwal D, Adsorption of heavy metals': a review. International Journal of Environmental Research and Development. 4: 41-48 (2004). 
8- Cossich E S, Tavares C R G, Ravagnani T M K. Biosorption of chromium (III) by Sargassum sp. Biomass. Electron. J. Biotechnol. 5 (2) August 15 Issue (2002).

9- Tokcaer E, and Yetis U. Pb (II)-Biosorption using anaerobically digested sludge. J. Hazard. Mater. B137: 1674-1680 (2006).

10- Lu W, Shi J, Wang C, and Chang J. Biosorption of lead, copper and cadmium by an indigenous isolate Enterobacter Sp. J1 possessing high heavy metal resistance. J. Hazard. Mater. B134: 80-86 (2006).

11- Garcia M A, Alonso J,and Melgar M J. Agaricus macrosporus as a potential bioremediation agent for substrates contaminated with heavy metals. $J$. Chem. Technol. Biotechnol. 80: 325-330 (2005).

12- Sune N, Sanchez G, Caffaratti S, and Maine M A. Cadmuim and chromium removal kinetics from solution by two aquatic macrophytes. Environ. Pollut. 145 : 467-473 (2007).

13- Khan M N, and Wahab M F. Characterization of chemically modified corncobs and its application in the removal of metal ions from aqueous solution. $J$. Hazard. Mater. 141: 237-244 (2007).

14- Khormaei M, Nasernejad B, Edrisi M, and Eslamzadeh T. Copper biosorption from aqueous solution by sour orange residue. . J. Hazard. Mater. 149 : 269-274 (2007).

15- Nouri L, Ghodbane I, Hamdaoui O, and Chiha M. Batch sorption dynamics and equilibrium for the removal of cadmium ions from aqueous phase using wheat bran. J. Hazard. Mater. 149: 115-125 (2007).

16- Uysal M, AR. Removal of Cr(VI) from Industrial Wastewaters by Adsorption Part1: Determination of Optimum Conditions. J. Hazard. Mater. 149: 482-491 (2007).

17- Nascimento R F, De Sousa F W, Neto V O S, Fechine P B A, Teixeira R N P, De Tarso P, Freire C, Araujo-Silva M A, in D. Sebayang (Eds.). Electroplating: Biomass Adsorbent for Removal of Toxic Metal Ions From Electroplating Industry Wastewater. Electroplating. InTech, 101-136 (2010).

18- Chefetz B. Decomposition and sorption characterization of plant cuticles in Soil. Plant Soil. 298 : 21-30 (2007).

19- Bouhamed F, Elouear Z, Bouzid J, and Ouddane B. Batch sorption dynamics and equilibrium for the removal of lead ions from aqueous phase using activated carbon developed from coffee residue activated with zinc chloride. Desal. Water Treat. 52: 2216 (2013).

20- Cuhadaroglu D, and Uygun O A. Production and characterization of activated carbon from a bituminous coal by chemical activation. African $J$. Biotechnol, 7: 2703-2710 (2008).

21- Hassan W, Farooq U, Ahmad M, Athar M, and Ain khan M. Potential biosorbent, Haloxylon recurvum plant stems, for the removal of methylene blue dye. Arab. J. Chem. 10: 1512-1522 (2017).

22- El-Sherif I Y, and Fathy N A. Modification of adsorptive properties of bagasse fly ash for uptaking cadmium from aqueous solution. Environmental Research, Engineering and Management, 2; 19-28 (2013).

23- Bayramoglu G, and Arica M Y. Biosorption of benzidine based textile dyes. Direct Blue 1 and Direct Red 128" using native and heat-treated biomass of Trametes versicolor. J. Hazard. Mater. 143, 135-143 (2007).

24- Mastalez M, and Bustin R M. Application of reflectance microFourier transform infrared spectrometry in studying coal macerals: comparison with other Fourier transform infrared techniques. Fuel. 74: 536-542 (1995).

25- Ouajai S, and Shanks R A. Composition, structure and thermal degradation of hemp cellulose after chemical treatments. Polym. Degrad. Stab., 89: 327-335 (2005).

26- Dharmalingam V, Ramasamy A K, and Balasuramania V. Chemical Modification on Reactive Dye Adsorption Capacity of Castor Seeds'. E-J. Chem. 8 : 335- 343 (2011).

27- Vieira M G A, De Almeida Neto A F, Carlos Da Silva M G, Nobrega C C, and Melo Filho A A. Characterization and use of in natura and calcined rice husks for biosorption of heavy metals ions from aqueous effluents. Braz. J.Chem. Eng. 29 :619-633 (2012).

28- Tarley C R T, and Arruda M A Z. Biosorption of Heavy Metal susing Rice Milling by-products. Characterisation and Application for Removal of Metals from Aqueous Effluents. Chemosphere, 54: 987-995 (2004).

29- Verma V K, and Mishra A K. Kinetic and isotherm modeling of adsorption of dyes onto rice husk carbon. Global NEST Journal, 12: 190-196 (2010).

30- Garg V K, Gupta R, Yadav B, and Kumar R. Dye removal from aqueous solution by adsorption on treated sawdust. Bioresour. Technol. 89: 121-124 (2003).

31- Kobya M, Demirbas E, Senturk E, Ince M. Adsorption of heavy metal ions from aqueous solutions by activated carbon prepared from apricot stone. Bioresour. Technol. 96: 1518-1521 (2005).

32- Ozer A, Akkaya G, and Turabik M. The biosorption of Acid Red 337 and Acid Blue 324 on Enteromorpha prolifera: The application of nonlinear regression analysis to dye biosorption. Chem. Eng. J. 112: 181-190 (2005).

33- Nwabanne J T, and Mordi M I. Equilibrium uptake and sorption dynamics for the removal of a basic dye using bamboo. African J. Biotechnol. 8: 15551559 (2009).

34- Awwad N S, Gad H M H, Ahmed M I, and Aly H F. Sorption of lanthanum and erbium from aqueous 
solution by activated carbon prepared from rice husk. Colloids Surf. B: Biointerfaces. 81: 593-599 (2010).

35- Jaikumar V, and Ramamurthi V. Effect of biosorption parameters kinetics isotherm and thermodynamics for acid green dye biosorption from aqueous solution by brewery waste. International Journal of Chemistry. 1: 2-12 (2009).

36- Mondal P, Majmder C B and Mohanty B. Effects of adsorbent dose, its particle size and initial arsenic concentration on the removal of arsenic, iron and manganese from simulated ground water by $\mathrm{Fe}^{3+}$ impregnated activated carbon. J. Hazard. Mater. 150: 695-702 (2008).

37- Dahlan I, Hassan S R,and Hakim M L. Removal of iron $\left(\mathrm{Fe}^{2+}\right)$ from aqueous solutions using siliceous waste sorbent, Sustain. Environment Research, 23: 41-48 (2013).

38- Tunc O, Tanaci H, and Aksu Z. Potential use of cotton plant wastes for the removal of Remazol Black B reactive dye. J. Hazard. Mater. 163: 87198 (2009).

39- Abdel-Galil E A. Chemical studies and sorption behavior of some hazardous metal ions on polyacrylamide stannic molybdophosphate as organic-inorganic composite cation - exchanger. Ph.D, Ain Shams University, Egypt (2010).

40- Jeon. C, and Park, K H. Adsorption and desorption characteristics of mercury(II) ions using aminated chitosan beads. Water Res. 36: 3938-3944 (2005).

41- Cho H, Oh D, and Kim K.A.A. Study on removal characteristics of heavy metals from aqueous solution by fly ash. J. Hazard. Mater. B127: 187195.

42- Unlu N, and Ersoz M. Adsorption characteristics of heavy metal ions onto a low cost biopolymer sorbent from aqueous solutions. J. Hazard. Mater. B136; 272-280 (2006).

43- Opeolu B.O, Bamgbose O., Arwolow T.A, and Adentunji M.T. Utilization of maize (Zea mays) cob as an adsorbent for lead (II) removal from aqueous solution. African J. Biotechnol.. 8: 15671573 (2009).

44- Nagah W.S.W, Hanafiah M.K.A.K.M. Bioresour. Technol. 99: 2935-2948 (2008).

45- Langmuir I. The constitution and fundamental properties of solids and liquids. Part I. Solids, $J$. Amer. Chem. Soc., 38 : 2221-2295 (1916).

46- Freundlich H M F. Uber die adsorption on losungen. Zeitschrift Fur Phys. ChemieStochiomet. Verwandt. 57: 385-471 (1906).

47- El-Naggar I.M, Sheneshen E.S, Abdel-Galil E.A. Retention behavior studies for the removal of some hazardous metal ions from waste solutions using polyaniline silicotitanate as composite cation exchanger. Desal. Water Treat. 56 (7): 1 (2014).

48- El-Naggar I M, Mowafy E A, Abdel-Galil E A, and El-Shahat M F. Synthesis, characterization and ion- exchange properties of a novel organicinorganic'hybrid cation-exchanger: polyacrylamide Sn (IV) molybdophosphate. Global J. Phys. Chem. 1:91-106 (2010).

49- El-Naggar I M, Zakaria E S, El-Kenany W M, and El-Shahat, M F. Synthesis and equilibrium studies of titanium vanadate and its use in the removal of some hazardous elements. Radiochemistry. 56, 86-91 (2014).

50- El-Naggar I M, Hebash K A, Sheneshen E S, and Abdel-Galil E A. Preparation, characterization and ion-exchange properties of a new organic inorganic composite cation exchanger polyaniline silicotitanate: Its applications for treatment of hazardous metal ions from waste solutions. Inorg. Chem. Indian J. 9: 1-14 (2014).

51- Boudrahem, F, Aissani-Benissad F and Aït-Amar H. Batch sorption dynamics and equilibrium for the removal of lead ions from aqueous phase using activated carbon developed from coffee residue activated with zinc chloride. J. Environ. Manage. 90: 3031 (2009).

52- Alam M Z and Ahmad S. Chromium removal through biosorption and bioaccumulation by bacteria from tannery eluents contaminated soil. Clean-Soil, Air, Water, 39 (3): 226 (2011).

53- Sekar M, Sakthi V and Rengaraj S. Kinetics and equilibrium adsorption study of lead(II) onto activated carbon prepared from coconut shell. $J$. Colloid Interface Sci, 279: 307 (2004).

54- Coleman N, Lee $\mathrm{W}$ and Slipper I. Interactions of aqueous $\mathrm{Cu}, \mathrm{Zn}$ and $\mathrm{Pb}$ ions with crushed concrete fines. J. Hazard. Mater. 121: 203 (2005).

55- Anwar J, Shaique U, Waheed-uz-Zaman, Salman M, Dar A and Anwar S. Removal of Pb(II) and Cd(II) from water by adsorption on peels of banana. Bioresour. Technol. 101: 1752 (2010).

56- Sar1 A and Tuzen M. Kinetic, equilibrium studies of biosorption of $\mathrm{Pb}(\mathrm{II})$ and $\mathrm{Cd}(\mathrm{II})$ from aqueous solution by macrofungus (Amanita rubescens) biomass. J. Hazard. Mater. 164, 1004 (2009).

57- Zein, R, Suhaili, Earnestly I, ndrawati and Munaf E. Removal of $\mathrm{Pb}(\mathrm{II}), \mathrm{Cd}(\mathrm{II})$ and $\mathrm{Co}(\mathrm{II})$ from aqueous solution using Garcinia mangostana L. fruit shell J. Hazard. Mater. 181: 52 (2010).

58- Ghaedi M, Ghezelbash G R, Marahel F, Ehsanipour S, Najibi A and Soylak M. Equilibrium, thermodynamic, and kinetic studies on lead (II) biosorption from aqueous solution by Saccharomyces cerevisiae biomass. CLEAN-Soil, Air, Water, 38: 877 (2010).

59- Abdel-Galil E A, Rizk H E and Mostafa A Z. Isotherm, kinetic, and thermodynamic studies for sorption of $\mathrm{Cu}(\mathrm{II})$ and $\mathrm{Pb}(\mathrm{II})$ by activated carbon prepared from Leucaena plant wastes. Part. Sci. Technol. 34 (5): 540 (2016). 